\title{
Association of Common Variants of $U C P 2$ Gene With Low-Grade Inflammation in Swedish Children and Adolescents; The European Youth Heart Study
}

\author{
IDOIA LABAYEN, FRANCISCO B. ORTEGA, MICHAEL SJÖSTRÖM, TORBJÖRN K. NILSSON, LOVISA A. OLSSON, \\ AND JONATAN R. RUIZ
}

\begin{abstract}
Department of Nutrition and Food Sciences [I.L.], University of the Basque Country, Vitoria 01006, Spain; Department of Biosciences and Nutrition at NOVUM [F.B.O., M.S., J.R.R.], Karolinska Institutet, Huddinge 14157, Sweden; Department of Physiology [F.B.O.], University of Granada, Granada 18012, Spain; Department of Clinical Chemistry [T.K.N., L.A.O.], Örebro University Hospital, Örebro University, Örebro 70185, Sweden
\end{abstract}

\begin{abstract}
We examined the associations of two functional variants $866 \mathrm{G}>\mathrm{A}$ and DEL/INS polymorphisms of UCP2 gene with low-grade inflammatory proteins (C-reactive protein, fibrinogen, complement $\mathrm{C} 3$ [C3], and complement $\mathrm{C} 4$ [C4]) in 131 children $(52.7 \%$ boys, aged $9.5 \pm 0.4 \mathrm{y})$ and 118 adolescents $(44.1 \%$ males, aged $15.5 \pm 0.4$ y) selected from the European Youth Heart Study. Differences in inflammatory markers among the genotype variants of the two UCP2 gene polymorphisms were analyzed after adjusting for sex, age, pubertal stage, fitness, and fatness. The results showed that fibrinogen, $\mathrm{C} 3$, and $\mathrm{C} 4$ were higher in GG carriers than in subjects carrying the A allele of the $866 \mathrm{G}>\mathrm{A}$ polymorphism of the $U C P 2$ gene (UCP2 $-866 \mathrm{G}>\mathrm{A}$ ) polymorphism (all $p<0.05)$. The DEL/ DEL genotype of $45 \mathrm{nt}$ deletion/insertion variant polymorphism of the $U C P 2$ gene (UCP2 DEL/INS) was associated with higher C3 $(p<$ $0.05)$ than DEL/INS and INS/INS genotypes. This study provides evidence of a role of $U C P 2-866 \mathrm{G}>\mathrm{A}$ in modifying low-grade inflammatory state in apparently healthy children and adolescents. Given the implication of complement factors on atherosclerosis process, these results contribute to explain the reduced cardiovascular risk associated with the A allele of the $U C P 2-866 \mathrm{G}>\mathrm{A}$ polymorphism. (Pediatr Res 66: 350-354, 2009)
\end{abstract}

$\mathrm{L}$ ow-grade inflammation seems to play an important role in the development of cardiovascular disease from early stages in life $(1,2)$. High concentration of C-reactive protein (CRP) and fibrinogen are considered a major cardiovascular risk factor (2,3). Likewise, the complement system has been implicated in the pathogenesis of atherosclerosis from early ages (4). It has been suggested that different complement factors have different preferential association with traditional risk factors (5). Complement C3 (C3) seems to represent a signal of the inflammatory process implicated in the appearance of the main endogenous risk factors such as glucose intolerance, type 2 diabetes, hypercholesterolemia, and hyper-

Received February 26, 2009; accepted May 10, 2009

Correspondence: Idoia Labayen, Ph.D., Department of Nutrition and Food Science, University of the Basque Country, Paseo de la Universidad, 7, Vitoria 01006, Spain; e-mail: idoia.labayen@ehu.es

Supported by grants from the Stockholm County Council, by the Swedish Council for Working Life and Social Research (2008-1108), and by the Spanish Ministry of Education (EX-2007-1124; AP-2004-2745).

Supplemental digital content is available for this article. Direct URL citations appear in the printed text and are provided in the HTML and PDF versions of this article on the journal's Web site (www.pedresearch.org). tension (6-8). Complement C4 (C4) concentration has been point out as an independent predictor of the future development of stroke (9).

The uncoupling protein (UCP) 2 is expressed in many tissues and cells, including macrophages (10) and it seems to have an important role in the regulation of production of reactive oxygen species (ROS), inhibition of inflammation as well as inhibition of cell death $(11,12)$, which are central features in cardiovascular disease. UCP2 has also an important role in the pathogenesis of type 2 diabetes by inhibiting insulin secretion in islet beta cells (13). At the same time, type 2 diabetes is associated with increased risk of cardiovascular disease and atherosclerosis, where an increased expression of UCP2 seems to be beneficial (14).

The $866 \mathrm{G}>\mathrm{A}$ polymorphism of the UCP2 gene (UCP2 $-866 \mathrm{G}>\mathrm{A})$ and the $45 \mathrm{nt}$ deletion/insertion variant polymorphism (UCP2 DEL/INS) located in the $3^{\prime}$-untranslated region of exon 8 are common variants in $U C P 2$ gene. Because of their implication on obesity or type 2 diabetes and obesity, they are attractive candidates to examining as potential risk factors for atherosclerosis.

Indeed, the $U C P 2-866 \mathrm{G}>\mathrm{A}$ seems to be functional variant on gene expression $(15,16)$. The common $-866 \mathrm{~A}$ allele variant has been associated with higher UCP2 mRNA levels $(15,16)$, decreased risk of obesity (17) and type 2 diabetes (18), as well as with reduced insulin secretion (19), although controversial outcomes were also obtained (20).

The polymorphism UCP2 DEL/INS polymorphism seemed to be functional (15), indeed previous studies have reported that the INS/DEL variant of UCP2 polymorphism could predispose to diabetes through multiple pathways affecting both insulin secretion and action (18).

To test the hypothesis that the $U C P 2$ gene locus contributes to the pathogenesis of atherosclerosis, we studied the associations of both $U C P 2-866 \mathrm{G}>\mathrm{A}$ and $U C P 2$ DEL/INS functional polymorphism variants with low-grade inflammatory

Abbreviations: C3, complement C3; C4, complement C4; CRP, C-reactive protein; EYHS, European Youth Heart Study; UCP, uncoupling protein; UCP2 -866G >A, 866G $>$ A polymorphism of the UCP2 gene; UCP2 DEL/ INS, 45 nt deletion/insertion variant polymorphism of the $U C P 2$ gene 
markers (CRP, fibrinogen, C3, and C4) in Swedish children aged 9-10 y and adolescents 15-16 y old, participating in the European Youth Heart Study.

\section{SUBJECTS AND METHODS}

Study participants. The EYHS was designed to examine the interactions among personal, environmental, and lifestyle influences on the risk factors for future cardiovascular diseases (21). Study design, selection criteria, and sample calculations have been reported elsewhere (21). Data collection took place from September 1998 to May 1999. The study was approved by the Research Ethics Committees of Örebro County Council (no. 690/98) and Huddinge University Hospital (no. 474/98). One parent or legal guardian provided written informed consent, and all children and adolescents gave verbal assent.

For this study, we included those subjects whose data on fibrinogen and DNA were available. As CRP concentrations $>10 \mathrm{mg} / \mathrm{L}$ may reflect an acute-phase response to infectious disease or disorders characterized by acute inflammation, three subjects (three boys, two children, and one adolescent) were excluded from the study. We also restricted the analysis to subjects apparently healthy with no contraindications to any of the study procedures and who were not taking medication that might influence the results. Therefore, a total of 131 children and 118 adolescents were included in this study.

Laboratory methods. Details of the blood sample analysis have been reported elsewhere (22). In brief, we analyzed all laboratory measurements in serum on a Hitachi 911 Analyzer (Roche Diagnostics, Indianapolis, IN) and at the same time to minimize systematic variation. Highly sensitive CRP was measured with a kit from Roche Diagnostics and had detection limits of $0.1-20 \mathrm{mg} / \mathrm{L}$ and a coefficient of variation (CV) of $<1.34 \%$. Fibrinogen, $\mathrm{C} 3$, and $\mathrm{C} 4$ were measured with kits from DakoCytomation (Glostrup, Denmark) and had sensitivities of $0.6-13.0,0.3-6.5$, and $0.06-1.30 \mathrm{~g} / \mathrm{L}$ and coefficients of variation of $<4.8,<2.7$, and $<3.9 \%$, respectively.

Total blood DNA was extracted and purified from $200 \mu \mathrm{L}$ of whole blood anticoagulated with EDTA, using the QIAamp DNA Blood Mini Kit by the spin procedure, according to the instructions of the manufacturer (QIAGEN Inc., Valencia, CA).

The UCP2 $-866 \mathrm{G}>\mathrm{A}$ (rs659366) polymorphism was genotyped by DNA sequencing using newly developed by Pyrosequencing assays (see supplemental material, Supplemental Digital Content 1, http://links.com/PDR/A48). The UCP2 DEL/INS polymorphism was analyzed by PCR followed by fragment size analysis on agarose gel electrophoresis (23).

Physical examination and cardiorespiratory fitness testing. Because it has been previously reported that a state of low-grade inflammation is positively associated with adiposity and negatively associated with cardiorespiratory and muscular fitness in children and adolescents $(22,24,25)$, the potential confounding role of these relevant factors were investigated (see supplemental material, Supplemental Digital Content 1, http://links.com/PDR/A48).

Height and weight were measured by standardized procedures. BMI was calculated as weight/height squared $\left(\mathrm{kg} / \mathrm{m}^{2}\right)$. Percentage of overweight and obese children and adolescents was calculated following the International Obesity Task Force that proposed gender- and age-adjusted BMI cutoff points (26). Skinfold thickness was measured with a Harpenden caliper (Baty International, Burgess, Hill, UK) at the biceps, triceps, subscapular, suprailiac, and triceps surae areas on the left side of the body according to the criteria described by Lohman (27). All measurements were taken twice and in rotation, and the mean value was calculated. If the difference between the measurements was more than $2 \mathrm{~mm}$, a third measurement was taken and the two closest measurements were averaged. The equations reported by Slaughter et al. (27) were used to calculate percentage body fat.

Pubertal stage was assessed by a trained researcher according to Tanner and Whitehouse (29).

Cardiorespiratory fitness was determined by a maximum cycle-ergometer test (30). Details of the protocol used can be found elsewhere $(22,31)$. Cardiorespiratory fitness was expressed as the maximal power output per kilogram body mass $(\mathrm{W} / \mathrm{kg}$ ). The test used to measure cardiorespiratory fitness has been previously validated in children of the same age (32).

Statistical analysis. Statistical analyses were performed with SPSS (v16.0 Chicago, IL). CRP, C4, and the sum of five skinfold thicknesses were normalized by transformation to the natural logarithm. Characteristics of the study sample by age group and sex are presented as means and SD, unless otherwise stated. Differences in age groups, pubertal status, gender distribution, and overweight and obesity prevalences of the genotype group variants were analyzed by $\chi^{2}$ test. Differences in age, fitness, and fatness, as estimated by the sum of five skinfolds, among the genotype group variants of polymorphisms were analyzed by one-way analysis of variance.
Differences in inflammatory markers among the genotype groups variants of the two UCP2 gene polymorphisms were analyzed by one-way analysis of covariance, before (model 1), after adjusting for sex, age, and pubertal stage (model 2), and after further adjusting for cardiorespiratory fitness and fatness (model 3). A $p$ value of $\leq 0.05$ was defined as statistically significant.

\section{RESULTS}

The descriptive characteristics of the study sample by age group and gender are shown in Table 1. C3 and C4 measurements were obtained from $96.8 \%$ of subjects ( 126 children, 61 girls and 115 adolescents, 64 females). Pubertal stage was obtained in $90.4 \%$ of the subjects. Cardiorespiratory fitness data were obtained in $91.6 \%$ of children and $94.9 \%$ of adolescents, and fatness, as estimated with the sum of five skinfold thicknesses, in $96.2 \%$ of children and $84.7 \%$ of adolescents.

Mean values of low-grade inflammatory markers were similar between the genders in both children and adolescents (for all, $p>0.1$ ). The correlation analysis between inflammatory markers (CRP, fibrinogen, $\mathrm{C} 3$, and C4), cardiorespiratory fitness, and fatness are shown in supplementary material (see supplemental material, Supplemental Digital Content 1, http://links.com/PDR/A48).

The distribution of the three genotype variants of the $U C P 2$ $-866 \mathrm{G}>\mathrm{A}$ between children and adolescents was significantly different $(p=0.010)$. However, there were no significant differences in children and adolescents distribution among the genotype groups of $U C P 2-866 \mathrm{G}>\mathrm{A}$ (GG versus $\mathrm{GA}+\mathrm{AA}$ ) and $U C P 2$ DEL/INS (DEL/DEL versus DEL/INS + INS/INS) polymorphisms $(p=0.811$ and $p=0.478$, respectively), neither in gender ( $p=0.842$ and $p=0.715$, respectively) and pubertal stage distributions ( $p=0.604$ and $p=0.295$, respectively) nor in overweight and obesity prevalence $(p=0.833$ and $p=0.950$, respectively). Age ( $p=$ 0.517 for $U C P 2-866 \mathrm{G}>\mathrm{A}$ and $p=0.813$ for $U C P 2 \mathrm{DEL} /$ INS), as well as fatness and fitness did not differ among genotype groups variants of both $U C P 2$ polymorphisms (for all $p>0.7$ ) (Fig. 1).

The effect of UCP2 -866G>A on low-grade inflammatory markers. The results showed that the $\mathrm{C} 4$ level was higher in subjects with GG genotype, than in $-866 \mathrm{~A}$ allele carriers $(p<0.05)$ of the UCP2 $-866 \mathrm{G}>\mathrm{A}$ polymorphism, in either the unadjusted or adjusted models (Table 2).

There were borderline trends to higher mean levels of fibrinogen and C3 ( $p<0.07$ for both) in subjects carrying the GG genotype than in those carrying the $-866 \mathrm{~A}$ allele (Table $2)$. These differences were statistically significant after adjusting for age, gender, and pubertal stage $(p<0.05)$, and they became stronger when both fatness and fitness were entered into the models (Table 2).

There were not genotype group variant related differences in CRP, glucose, or insulin (Table 2).

The effect of UCP2 DEL/INS on low-grade inflammatory markers. The DEL/INS polymorphism of UCP2 gene-related differences in unadjusted inflammatory markers concentration was only significant for C3 $(p<0.05)$, and further adjusting for the main confounders (model 2 and 3) did not materially change the results (Table 3 ). 
Table 1. Characteristics of the study sample by age group and gender

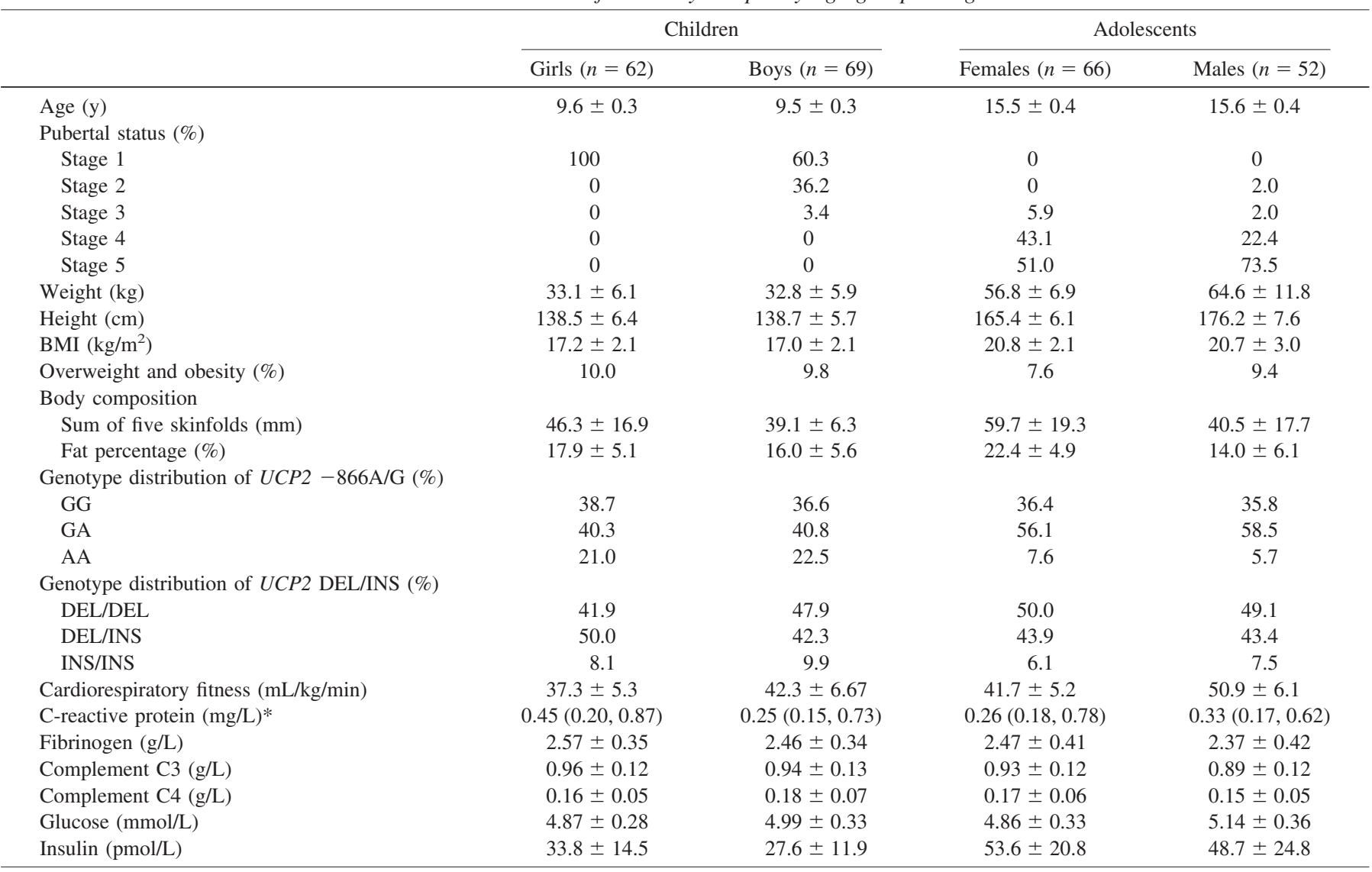

All values are mean $\pm \mathrm{SD}$, unless otherwise stated.

* Values are median (P25, P75).

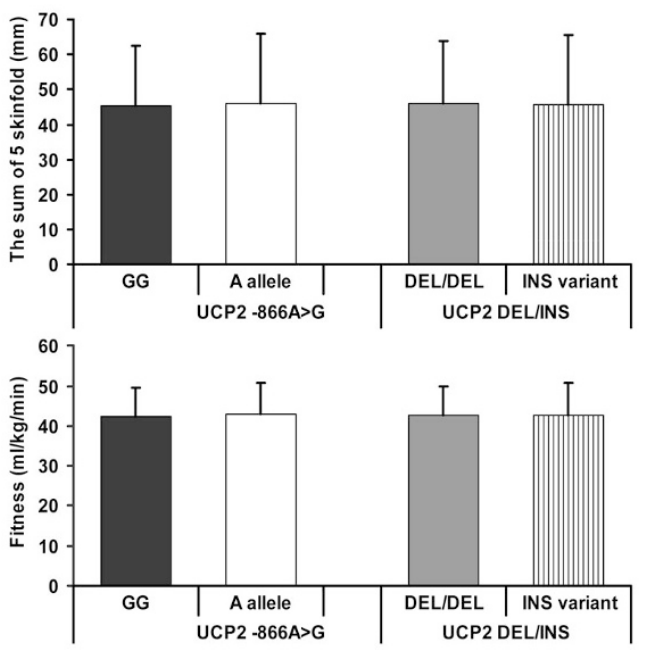

Figure 1. Mean values of the sum of five skinfold thicknesses and cardiorespiratory fitness according to genotype groups of $U C P 2-866 \mathrm{G}>\mathrm{A}$ and UCP2 DEL/INS polymorphisms. Errors bars represent SD. Analysis was performed on log-transformed data, but nontransformed data are presented in the figure ( $p$ for all $>0.6$ ).

\section{DISCUSSION}

This study indicates that the $-866 \mathrm{GG}$ genotype of the $U C P 2-866 \mathrm{G}>\mathrm{A}$ polymorphism is associated with higher low-grade inflammatory state in apparently healthy Swedish children and adolescents. In addition, DEL/DEL genotype of the UCP2 DEL/INS polymorphism was related to increased $\mathrm{C} 3$ levels in this population.

We used a single blood measurement of inflammation that may not accurately reflect long-term inflammatory status. Although no subject with previously diagnosed cardiovascular pathologies or a known underlying cause of infection was included, we cannot exclude that possible elevated concentrations were due to the onset of an infection. Because of the relatively small sample size, the results of this study should be considered as preliminary findings and should be replicated in further studies.

To our knowledge, there is no previous data reporting the role of $U C P 2-866 \mathrm{G}>\mathrm{A}$ and $U C P 2$ DEL/INS polymorphisms on low-grade inflammatory markers levels, which hamper comparison with other studies. Our findings are related with previous studies showing a protective effect of $-866 \mathrm{~A}$ allele of $U C P 2-866 \mathrm{G}>\mathrm{A}$ and INS allele of $U C P 2$ DEL/INS polymorphisms on cardiovascular disease risk factors, mediated by an increased expression or activity of UCP2.

The precise function of UCP2 is still unclear, but it has shown to be linked to mitochondria-derived ROS production and in the inhibition of inflammation. Thus, the chronic absence of UCP2 has the potential to promote persistent ROS accumulation and an oxidative stress response (33). Increased ROS production contributes to the pathogenesis of atherosclerosis. Whereas in resting conditions UCP2 expression in 
Table 2. Low-grade inflammatory markers, glucose and insulin concentrations according to genotype variants groups of the UCP2 $-866 \mathrm{~A}>\mathrm{G}$ polymorphism in children and adolescents

\begin{tabular}{|c|c|c|c|c|c|c|c|c|c|}
\hline & \multicolumn{3}{|c|}{ Unadjusted } & \multicolumn{3}{|c|}{$\begin{array}{l}\text { Adjusted with age, gender, } \\
\text { and puberty stage }\end{array}$} & \multicolumn{3}{|c|}{$\begin{array}{l}\text { Adjusted with age, gender, } \\
\text { puberty stage, fatness, and fitness }\end{array}$} \\
\hline & $\mathrm{GG}(n=103)$ & $\begin{array}{l}\mathrm{GA}+\mathrm{AA} \\
(n=177)\end{array}$ & $p$ & $\mathrm{GG}(n=94)$ & $\begin{array}{l}\mathrm{GA}+\mathrm{AA} \\
(n=158)\end{array}$ & $p$ & GG $(n=77)$ & $\begin{array}{l}\mathrm{GA}+\mathrm{AA} \\
(n=138)\end{array}$ & $p$ \\
\hline C-reactive protein $(\mathrm{mg} / \mathrm{L})^{*}$ & $0.85 \pm 1.70$ & $1.20 \pm 4.71$ & 0.504 & $0.83 \pm 0.44$ & $1.16 \pm 0.34$ & 0.542 & $0.89 \pm 0.52$ & $1.20 \pm 0.39$ & 0.309 \\
\hline Fibrinogen $(\mathrm{g} / \mathrm{l})$ & $2.53 \pm 0.38$ & $2.44 \pm 0.43$ & 0.067 & $2.54 \pm 0.38$ & $2.41 \pm 0.42$ & 0.017 & $2.53 \pm 0.41$ & $2.38 \pm 0.40$ & 0.007 \\
\hline Complement C3 (g/L) & $0.95 \pm 0.13$ & $0.92 \pm 0.13$ & 0.062 & $0.96 \pm 0.13$ & $0.92 \pm 0.12$ & 0.036 & $0.96 \pm 0.13$ & $0.92 \pm 0.12$ & 0.010 \\
\hline Complement C4 (g/l)* & $0.18 \pm 0.06$ & $0.16 \pm 0.06$ & 0.032 & $0.18 \pm 0.06$ & $0.17 \pm 0.06$ & 0.033 & $0.18 \pm 0.06$ & $0.16 \pm 0.06$ & 0.015 \\
\hline Glucose $(\mathrm{mmol} / \mathrm{L})$ & $4.94 \pm 0.32$ & $4.97 \pm 0.35$ & 0.579 & $4.94 \pm 0.33$ & $4.97 \pm 0.35$ & 0.573 & $4.95 \pm 0.35$ & $4.97 \pm 0.35$ & 0.869 \\
\hline Insulin (pmol/L) & $41.3 \pm 18.8$ & $40.5 \pm 22.3$ & 0.759 & $41.6 \pm 19.2$ & $40.2 \pm 22.8$ & 0.399 & $40.4 \pm 18.3$ & $40.5 \pm 23.5$ & 0.490 \\
\hline
\end{tabular}

Values are means \pm SD.

* Analysis was performed on log-transformed data, but non-transformed data are presented in the table.

Table 3. Low-grade inflammatory markers, glucose and insulin concentrations according to genotype variants groups of the UCP2 DEL/INS polymorphisms in children and adolescents

\begin{tabular}{|c|c|c|c|c|c|c|c|c|c|}
\hline & \multicolumn{3}{|c|}{ Unadjusted } & \multicolumn{3}{|c|}{$\begin{array}{l}\text { Adjusted with age, gender, and } \\
\text { puberty stage }\end{array}$} & \multicolumn{3}{|c|}{$\begin{array}{l}\text { Adjusted with age, gender, puberty } \\
\text { stage, fatness, and fitness }\end{array}$} \\
\hline & $\begin{array}{l}\text { DEL/DEL } \\
(n=129)\end{array}$ & $\begin{array}{l}\text { INS variant } \\
(n=151)\end{array}$ & $p$ & $\begin{array}{l}\text { DEL/DEL } \\
(n=115)\end{array}$ & $\begin{array}{l}\text { INS variant } \\
(n=137)\end{array}$ & $p$ & $\begin{array}{l}\text { DEL/DEL } \\
(n=100)\end{array}$ & $\begin{array}{l}\text { INS variant } \\
(n=115)\end{array}$ & $p$ \\
\hline C-reactive protein $(\mathrm{mg} / \mathrm{L})^{*}$ & $1.48 \pm 5.49$ & $0.71 \pm 1.18$ & 0.161 & $1.45 \pm 5.75$ & $0.67 \pm 1.02$ & 0.281 & $1.59 \pm 6.18$ & $0.64 \pm 1.04$ & 0.410 \\
\hline Fibrinogen $(\mathrm{g} / \mathrm{L})$ & $2.51 \pm 0.45$ & $2.44 \pm 0.38$ & 0.202 & $2.51 \pm 0.44$ & $2.42 \pm 0.38$ & 0.064 & $2.47 \pm 0.45$ & $2.40 \pm 0.37$ & 0.235 \\
\hline Complement C3 (g/L) & $0.95 \pm 0.13$ & $0.92 \pm 0.12$ & 0.029 & $0.96 \pm 0.13$ & $0.92 \pm 0.12$ & 0.007 & $0.95 \pm 0.13$ & $0.91 \pm 0.012$ & 0.019 \\
\hline Complement C4 $(\mathrm{g} / \mathrm{L})^{*}$ & $0.17 \pm 0.06$ & $0.17 \pm 0.06$ & 0.491 & $0.18 \pm 0.06$ & $0.17 \pm 0.06$ & 0.488 & $0.167 \pm 0.06$ & $0.17 \pm 0.06$ & 0.957 \\
\hline Glucose $(\mathrm{mmol} / \mathrm{L})$ & $4.97 \pm 0.34$ & $4.94 \pm 0.33$ & 0.562 & $4.98 \pm 0.35$ & $4.94 \pm 0.33$ & 0.561 & $4.98 \pm 0.37$ & $4.94 \pm 0.34$ & 0.528 \\
\hline Insulin (pmol/L) & $41.9 \pm 19.7$ & $39.8 \pm 22.1$ & 0.409 & $42.8 \pm 20.4$ & $38.9 \pm 22.3$ & 0.223 & $42.8 \pm 20.2$ & $38.4 \pm 22.9$ & 0.268 \\
\hline
\end{tabular}

Values are means $\pm \mathrm{SE}$.

* Analysis was performed on log-transformed data, but non-transformed data are presented in the table.

vascular cells is very low, oxidative stress rapidly increases the protein expression. The overexpression of UCP2 seems to protect cells against oxidative stress (34). Thus, functional $U C P 2$ gene polymorphisms leading to reduced expression of UCP2 and, consequently, reducing the protection of vasculature against ROS, could be related to higher inflammatory levels and to the development and progression of atherosclerosis. On the other hand, it has been suggested that agedepending genetic and environmental factors may be involved in UCP2 regulation. Thus, UCP2 expression increases after birth and decreases later in life (35). In addition, infants have a higher nutritional intake (in $\mathrm{g} / \mathrm{kg}$ body weight and day) than adults, and as glucose and fatty acids increased the UCP2 transcription, UCP2 dysfunction may have higher physiopathological implications in children than in adults (36).

The $-866 \mathrm{~A}$ allele has been associated with higher UCP2 transcriptional activity in transfected cultured cells (15). However, the effect of carrying the $-866 \mathrm{~A}$ allele in human tissues has been conflicting, reporting either increased (16) or decreased $(18,37)$ mRNA expression. The $\mathrm{G}$ allele was also associated with a higher prevalence of obesity and in a decreased expression of UCP2 in the study of Esterbauer et al. (15). These results agree with Wang et al. findings (18) that showed a trend toward association between the $-866 \mathrm{G}$ allele and type 2 diabetes. Furthermore, previous studies conducted in children reported that those carrying the $\mathrm{G}$ allele of $U C P 2$ $-866 \mathrm{G}>\mathrm{A}$ were at higher obesity risk as estimated by higher BMI $(15,17,38,39)$. Other reports, however, found no evidence for involvement of the promoter polymorphism -866 G/A of the UCP2 gene in childhood-onset obesity (40).
Unfortunately, none of them measured body fat mass content. Because obesity is characterized by a state of chronic lowgrade inflammation, which could accelerate vascular damages, differences in fat mass could explain the higher inflammation found in subjects carrying the GG genotype. However, this hypothesis is unlikely because we did not observe differences in both BMI and fat mass content across genotype groups. We reported that a state of low-grade inflammation is positively associated with adiposity and negatively associated with cardiorespiratory and muscular fitness in children and adolescents $(22,24,25)$, therefore both fatness and fitness were entered as covariates into the model. Moreover, current research point at that UCP2 does not seem to play a key role in thermogenesis or weight control (12).

The $U C P 2$ DEL/INS polymorphism had a weaker effect on low-grade inflammatory markers, which concur with previous studies $(23,37)$. The $45 \mathrm{bp}$ insertion presented a trend to be a protector factor against insulin resistance in either diabetic patients or healthy adults (15), whereas no impact on mRNA expression or insulin secretion has been reported (18). In our study, there were not differences according to genotype variants of UCP2 DEL/INS polymorphism with regard to BMI or fatness, and neither to plasma glucose nor to insulin. Yanovski et al. (41) reported statistically significant associations in a small sample of children between DEL/INS genotype variant and both BMI and total body fat. However, the study was conducted in a sample in which all the children were obese themselves or for whom both parents had a history of overweight or obesity, which hamper comparisons. 
In conclusion, this study provides the first evidence of a role of $U C P 2-866 \mathrm{G}>\mathrm{A}$ polymorphism in modifying low-grade inflammatory status in apparently healthy Swedish children and adolescents. DEL/DEL genotype of the UCP2 DEL/INS polymorphism was also related to increased C3 levels. Given the implication of complement factors on atherosclerosis process, these results contribute to explain the reduced cardiovascular risk associated with the A allele of the UCP2 $-866 \mathrm{G}>\mathrm{A}$ polymorphism. Further studies are needed to confirm or discard our findings.

\section{REFERENCES}

1. Jarvisalo MJ, Harmoinen A, Hakanen M, Paakkunainen U, Viikari J, Hartiala J, Lehtimaki T, Simell O, Raitakari OT 2002 Elevated serum C-reactive protein levels and early arterial changes in healthy children. Arterioscler Thromb Vasc Biol 22:1323-1328

2. Hansson GK 2005 Inflammation, atherosclerosis, and coronary artery disease. N Engl J Med 352:1685-1695

3. Athyros VG, Kakafika AI, Karagiannis A, Mikhailidis DP 2008 Do we need to consider inflammatory markers when we treat atherosclerotic disease? Atherosclerosis 200:1-12

4. Millonig G, Malcom GT, Wick G 2002 Early inflammatory-immunological lesions in juvenile atherosclerosis from the Pathobiological Determinants of Atherosclerosis in Youth (PDAY)-study. Atherosclerosis 160:441-448

5. Onat A, Uzunlar B, Hergenc G, Yazici M, Sari I, Uyarel H, Can G, Sansoy V 2005 Cross-sectional study of complement $\mathrm{C} 3$ as a coronary risk factor among men and women. Clin Sci (Lond) 108:129-135

6. Muscari A, Bastagli L, Poggiopollini G, Tomassetti V, Massarelli G, Cappelletti O, Plate L, Boni P, Puddu P 2002 Different associations of C-reactive protein, fibrinogen and $\mathrm{C} 3$ with traditional risk factors in middle-aged men. Int J Cardiol 83:63-71

7. Engstrom G, Hedblad B, Eriksson KF, Janzon L, Lindgarde F 2005 Complement C3 is a risk factor for the development of diabetes: a population-based cohort study. Diabetes 54:570-575

8. Zhang X, Hu K, Li CY 2001 Protection against oxidized low-density lipoproteininduced vascular endothelial cell death by integrin-linked kinase. Circulation 104:2762-2766

9. Cavusoglu E, Eng C, Chopra V, Ruwende C, Yanamadala S, Clark LT, Pinsky DJ, Marmur JD 2007 Usefulness of the serum complement component C4 as a predictor of stroke in patients with known or suspected coronary artery disease referred for coronary angiography. Am J Cardiol 100:164-168

10. Giardina TM, Steer JH, Lo SZ, Joyce DA 2008 Uncoupling protein-2 accumulates rapidly in the inner mitochondrial membrane during mitochondrial reactive oxygen stress in macrophages. Biochim Biophys Acta 1777:118-129

11. Arsenijevic D, Onuma H, Pecqueur C, Raimbault S, Manning BS, Miroux B, Couplan E, Alves-Guerra MC, Goubern M, Surwit R, Bouillaud F, Richard D, Collins S, Ricquier D 2000 Disruption of the uncoupling protein-2 gene in mice reveals a role in immunity and reactive oxygen species production. Nat Genet 26:435-439

12. Mattiasson G, Sullivan PG 2006 The emerging functions of UCP2 in health, disease, and therapeutics. Antioxid Redox Signal 8:1-38

13. Englund U, Littbrand H, Sondell A, Pettersson U, Bucht G 2005 A 1-year combined weight-bearing training program is beneficial for bone mineral density and neuromuscular function in older women. Osteoporos Int 16:1117-1123

14. Gable DR, Stephens JW, Cooper JA, Miller GJ, Humphries SE 2006 Variation in the UCP2-UCP3 gene cluster predicts the development of type 2 diabetes in healthy middle-aged men. Diabetes 55:1504-1511

15. Esterbauer H, Schneitler C, Oberkofler H, Ebenbichler C, Paulweber B, Sandhofer F, Ladurner G, Hell E, Strosberg AD, Patsch JR, Krempler F, Patsch W 2001 A common polymorphism in the promoter of UCP2 is associated with decreased risk of obesity in middle-aged humans. Nat Genet 28:178-183

16. Krempler F, Esterbauer H, Weitgasser R, Ebenbichler C, Patsch JR, Miller K, Xie M, Linnemayr V, Oberkofler H, Patsch W 2002 A functional polymorphism in the promoter of UCP2 enhances obesity risk but reduces type 2 diabetes risk in obese middle-aged humans. Diabetes 51:3331-3335

17. Ochoa MC, Santos JL, Azcona C, Moreno-Aliaga MJ, Martinez-Gonzalez MA, Martinez JA, Marti A, Members G 2007 Association between obesity and insulin resistance with UCP2-UCP3 gene variants in Spanish children and adolescents. Mol Genet Metab 92:351-358

18. Wang H, Chu WS, Lu T, Hasstedt SJ, Kern PA, Elbein SC 2004 Uncoupling protein-2 polymorphisms in type 2 diabetes, obesity, and insulin secretion. Am J Physiol Endocrinol Metab 286:E1-E7
19. Sesti G, Cardellini M, Marini MA, Frontoni S, D'Adamo M, Del Guerra S, Lauro D, De Nicolais P, Sbraccia P, Del Prato S, Gambardella S, Federici M, Marchetti P, Lauro R 2003 A common polymorphism in the promoter of UCP2 contributes to the variation in insulin secretion in glucose-tolerant subjects. Diabetes 52:1280-1283

20. D’Adamo M, Perego L, Cardellini M, Marini MA, Frontoni S, Andreozzi F, Sciacqua A, Lauro D, Sbraccia P, Federici M, Paganelli M, Pontiroli AE, Lauro R, Perticone F, Folli F, Sesti G 2004 The -866A/A genotype in the promoter of the human uncoupling protein 2 gene is associated with insulin resistance and increased risk of type 2 diabetes. Diabetes 53:1905-1910

21. Wennlof AH, Yngve A, Sjostrom M 2003 Sampling procedure, participation rates and representativeness in the Swedish part of the European Youth Heart Study (EYHS). Public Health Nutr 6:291-299

22. Ruiz JR, Ortega FB, Warnberg J, Sjostrom M 2007 Associations of low-grade inflammation with physical activity, fitness and fatness in prepubertal children; the European Youth Heart Study. Int J Obes (Lond) 31:1545-1551

23. Dalgaard LT, Sorensen TI, Andersen T, Hansen T, Pedersen O 1999 An untranslated insertion variant in the uncoupling protein 2 gene is not related to body mass index and changes in body weight during a 26-year follow-up in Danish Caucasian men. Diabetologia 42:1413-1416

24. Warnberg J, Nova E, Moreno LA, Romeo J, Mesana MI, Ruiz JR, Ortega FB, Sjostrom M, Bueno M, Marcos A 2006 Inflammatory proteins are related to total and abdominal adiposity in a healthy adolescent population: the AVENA Study. Am J Clin Nutr 84:505-512

25. Ruiz JR, Ortega FB, Warnberg J, Moreno LA, Carrero JJ, Gonzalez-Gross M, Marcos A, Gutierrez A, Sjostrom M 2008 Inflammatory proteins and muscle strength in adolescents: the Avena study. Arch Pediatr Adolesc Med 162:462-468

26. Cole TJ, Bellizzi MC, Flegal KM, Dietz WH 2000 Establishing a standard definition for child overweight and obesity worldwide: international survey. BMJ 320:12401243

27. Slaughter MH, Lohman TG, Boileau RA, Horswill CA, Stillman RJ, Van Loan MD, Bemben DA 1988 Skinfold equations for estimation of body fatness in children and youth. Hum Biol 60:709-723

28. Rodriguez G, Moreno LA, Blay MG, Blay VA, Fleta J, Sarria A, Bueno M 2005 Body fat measurement in adolescents: comparison of skinfold thickness equations with dual-energy X-ray absorptiometry. Eur J Clin Nutr 59:1158-1166

29. Tanner JM, Whitehouse RH 1976 Clinical longitudinal standards for height, weight, height velocity, weight velocity, and stages of puberty. Arch Dis Child 51:170-179

30. Hansen HS, Froberg K, Nielsen JR, Hyldebrandt N 1989 A new approach to assessing maximal aerobic power in children: the Odense School Child Study. Eur J Appl Physiol Occup Physiol 58:618-624

31. Ortega FB, Ruiz JR, Hurtig-Wennlof A, Vicente-Rodriguez G, Rizzo NS, Castillo MJ, Sjostrom M. Cardiovascular fitness modifies the associations between physical activity and abdominal adiposity in children and adolescents. The European Youth Heart Study. Br J Sports Med, in press

32. Riddoch C, Edwards D, Page A, Froberg K, Anderssen S, Wedderkopp N, Brage S, Cooper AR, Sardinha LB, Harro M, Klasson-Heggebo L, van Mechelen W, Boreham C, Ekelund U, Andersen LB, and the European Youth Heart Study team 2005 European Youth Heart Study-Cardiovascular disease risk factors in children: Rationale, aims, study design, and validation of methods. J Phys Act Health 2:115-129

33. Pi J, Bai Y, Daniel KW, Liu D, Lyght O, Edelstein D, Brownlee M, Corkey BE, Collins S. Persistent oxidative stress due to absence of uncoupling protein 2 associated with impaired pancreatic beta-cell function. Endocrinology, in press

34. Kim HS, Park KG, Koo TB, Huh S, Lee IK 2007 The modulating effects of the overexpression of uncoupling protein 2 on the formation of reactive oxygen species in vascular cells. Diabetes Res Clin Pract 77:S46-S48

35. Saleh MC, Wheeler MB, Chan CB 2006 Endogenous islet uncoupling protein-2 expression and loss of glucose homeostasis in ob/ob mice. J Endocrinol 190:659667

36. Patane G, Anello M, Piro S, Vigneri R, Purrello F, Rabuazzo AM 2002 Role of ATP production and uncoupling protein-2 in the insulin secretory defect induced by chronic exposure to high glucose or free fatty acids and effects of peroxisome proliferator-activated receptor-gamma inhibition. Diabetes 51:2749-2756

37. Oberkofler H, Iglseder B, Klein K, Unger J, Haltmayer M, Krempler F, Paulweber B, Patsch W 2005 Associations of the UCP2 gene locus with asymptomatic carotid atherosclerosis in middle-aged women. Arterioscler Thromb Vasc Biol 25:604-610

38. Jun HS, Kim IK, Lee HJ, Kang JH, Kim JR, Shin HD, Song J 2009 Effects of UCP2 and UCP3 variants on the manifestation of overweight in korean children. Obesity (Silver Spring) 17:355-362

39. Le Fur S, Le Stunff C, Dos Santos C, Bougneres P 2004 The common -866 G/A polymorphism in the promoter of uncoupling protein 2 is associated with increased carbohydrate and decreased lipid oxidation in juvenile obesity. Diabetes 53:235-239

40. Schauble N, Geller F, Siegfried W, Goldschmidt H, Remschmidt H, Hinney A, Hebebrand J 2003 No evidence for involvement of the promoter polymorphism $-866 \mathrm{G} / \mathrm{A}$ of the UCP2 gene in childhood-onset obesity in humans. Exp Clin Endocrinol Diabetes 111:73-76

41. Yanovski JA, Diament AL, Sovik KN, Nguyen TT, Li H, Sebring NG, Warden CH 2000 Associations between uncoupling protein 2, body composition, and resting energy expenditure in lean and obese African American, white, and Asian children. Am J Clin Nutr 71:1405-1420 